\title{
Rationale, experience and ethical considerations underpinning integrated actions to further global goals for health and land biodiversity in Papua New Guinea
}

\author{
Jo Middleton ${ }^{1,2}$ - Jackie A. Cassell ${ }^{1}$ - Gavin Colthart ${ }^{1} \cdot$ Francesca Dem $^{3}$. James Fairhead ${ }^{4} \cdot$ Michael G. Head $^{5}$. \\ Joao Inacio ${ }^{6,7} \cdot$ Mavis Jimbudo ${ }^{3}$ Moses Laman ${ }^{8} \cdot$ Vojtech Novotny ${ }^{3,9,10} \cdot$ Mika Peck $^{2} \cdot$ Jonah Philip $^{3} \cdot$ William Pomat $^{8}$. \\ Shen Sui ${ }^{3} \cdot$ Peter West-Oram $^{11} \cdot$ Alan Stewart $^{2}$
}

Received: 3 July 2019 / Accepted: 13 April 2020 / Published online: 30 April 2020

(c) The Author(s) 2020

\begin{abstract}
The SURFACES project is integrating action on good health and wellbeing [Sustainable Development Goal (SDG) 3] and conservation of life on land (SDG 15) in the threatened rainforests of Papua New Guinea (PNG), and mapping evidence of similar projects worldwide. Our approach is framed by Planetary Health, aiming to safeguard both human health and the natural systems that underpin it. Our rationale is demonstrated through a summary of health needs and forest conservation issues across PNG, and how these play out locally. We outline differing types of integrated conservation and health interventions worldwide, providing examples from Borneo, Uganda, India and elsewhere. We then describe what we are doing on-the-ground in PNG, which includes expansion of a rainforest conservation area alongside the establishment of a nurse-staffed aid post, and an educational intervention conceptually linking forest conservation and health. Importantly, we explore some ethical considerations on the conditionality of medical provision and identify key challenges to the successful implementation of such projects. The latter include: avoiding cross-sectoral blindness and achieving genuine interdisciplinary working; the weak evidence base justifying projects; and temporal-spatial issues. We conclude by suggesting how projects integrating actions on health and conservation SDGs can benefit from (and contribute to) the energy of the emerging Planetary Health movement.
\end{abstract}

Keywords Sustainable development goals $\cdot$ Planetary health $\cdot$ Papua New Guinea $\cdot$ Health services $\cdot$ Rainforest conservation

Handled by John Thompson, Institute of Development Studies Rural Futures, United Kingdom.

Jo Middleton

j.middleton@bsms.ac.uk

1 Department of Primary Care and Public Health, Brighton and Sussex Medical School, Room 318a, Watson Building, Falmer BN1 9PH, UK

2 Evolution, Behaviour and Environment, School of Life Sciences, University of Sussex, Falmer, UK

3 New Guinea Binatang Research Centre, Madang, Papua New Guinea

4 Anthropology, School of Global Studies, University of Sussex, Falmer, UK

5 Faculty of Medicine and Global Health Research Institute, University of Southampton, Southampton, UK
6 School of Pharmacy and Biomolecular Sciences, University of Brighton, Brighton, UK

7 Department of Global Health and Tropical Medicine, Institute of Hygiene and Tropical Medicine, Lisbon, Portugal

8 Papua New Guinea Institute of Medical Research, Madang/Goroko, Papua New Guinea

9 Department of Ecology and Conservation Biology, Czech Academy of Sciences, Prague, Czech Republic

10 University of South Bohemia, Ceske Budejovice, Czech Republic

11 Biomedical Ethics, Department of Clinical and Experimental Medicine, Brighton and Sussex Medical School, Falmer, UK 


\section{Health needs and rainforest conservation in Papua New Guinea (PNG)}

The island of New Guinea lies in the South Pacific, north of Australia. PNG, its eastern half, is ranked 155 of 188 countries by SDG health indicator scores, of which only two countries outside sub-Saharan Africa score worse (Lim et al. 2016). The Maternal Mortality is high, at 773 deaths per 100,000 live births in 2007, and 230 per 100,000 in 2010 (although this downward trend may be due to methodological variation) (Bolnga et al. 2014). Similarly, infant mortality is high, 61 deaths per 1000 live births (Pilang et al. 2017). Projected life expectancy for those born in 2015 is 61y for males and 66y for females (WHO 2018a), markedly lower than neighbouring countries: Indonesia, 67/71y (WHO 2018b); Australia, 81/85y (WHO 2018c). While impressive gains have been made in reducing deaths from some targeted diseases, especially malaria (WHO 2016), global medical neglect (particularly of remote communities) has left the top eight health problems that cause the most disability [years lived with disability (YLDs)] unchanged for 15 years (IHME 2018).

New Guinea has the Earth's third-largest remaining tropical rainforest (Shearman and Bryan 2011) with PNG home to 5\% of all animal and plant species, many found nowhere else (Novotny and Toko 2015). Though unusually retaining a much larger percentage of intact habitat than other regions of global conservation concern such as the biodiversity hotspots (Mittermeier et al. 1998), the fate of PNGs forests will still most likely be decided in one human generation (Novotny and Toko 2015). Deforestation is following the unsustainable pattern seen in other tropical forests, with one-quarter of PNGs forest cleared or degraded (Shearman and Bryan 2011). Nearly half these changes have been caused by commercial logging (Sherman et al. 2009), carried out in a weak governance context in which corporate actors plan development far removed from forest villages (Laurance et al. 2012, 2010; Nelson et al. 2014).

97\% of PNG is owned or claimed by clans as communal property, offering a potential counterweight against destructive pressures emanating from global commodity demands (Laurance et al. 2012). However, lacking alternative development options many clans take inducements from extractive industries (Novotny 2010). The United Nations vision of sustainable development (itself a development model authored far from PNGs forest communities) requires protecting life on land (SDG 15) and supporting good health (SDG 3) (UN 2018). Yet these goals may seem in conflict to some remote clans in PNG with low levels of health provision. Logging companies' offer of roads and income can decrease remoteness from health
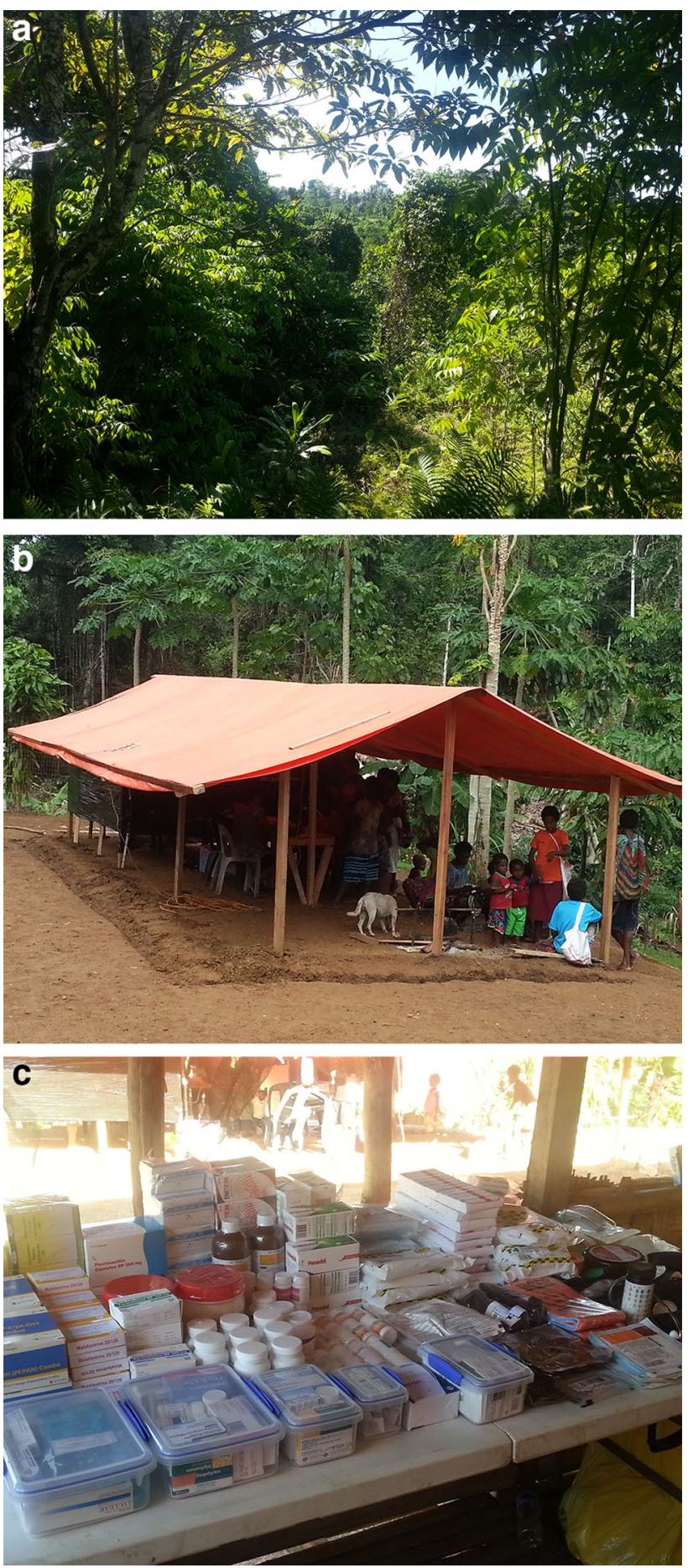

Fig. 1 Wanang Conservation Area health needs assessment. a tropical rainforest around Wanang village; b research and treatment shelter with spaces for private clinical examinations and a waiting 'room' with an admin desk and cooking fire. In the evening the shelter hosted community discussions on health service priorities; $\mathbf{c}$ medicines stock for the treatment of urgent cases 
services, making the desire for health a driver for forest destruction and erosion of health-related ecosystem services. This potential competition between health service access and biodiversity conservation has been noted on other forest frontiers (Ali and Jacobs 2007; Wan et al. 2011). Loggers in PNG have further taken advantage of this dynamic during land-access negotiations and promised to build on-site health services and provide evacuation to hospital along logging roads (Wagia 2018). Given that conservation success in PNG fundamentally relies on what forest communities judge is in their best interest (Novotny 2010), synergies must be developed with the delivery of other SDGs, particularly those pertaining to health.

PNG clans in the lowland forests centred around the village of Wanang have put in place multi-stakeholder agreements preserving their forest homes whilst giving them access to opportunities for development. In 2000 nine clans agreed to preserve 10,000 ha of forest, whilst surrounding communities allowed their lands to be logged (Henning 2015). The subsequent conservation collaboration, the Wanang Conservation Area (WCA) (https://baloun.entu.cas. cz/png/wanang/), is led by the villagers working with the New Guinea Binatang Research Centre (BRC), University of Sussex (UoS), and other international institutions. It has brought benefits including schooling, income, international travel, and parabiologist training (Basset et al. 2004). This has transformed the forest into a research-rich environment providing development whilst conserving biodiversity (University of Sussex 2014). The project provides an example of methods, practices and institutions to address SDGs, and was recognized by the UN Development Programme as an 'outstanding local achievement in advancing sustainable development for people, nature, and resilient communities', by the Equator Prize at the 2015 Paris Climate Change Conference (University of Sussex 2015). However, there are no medical services at Wanang, and villagers have to travel approximately $80 \mathrm{~km}$ to a regional hospital. As a result, villagers requested health services be developed as part of the conservation collaboration (Stewart et al. 2016). Below we outline our current work in the SURFACES project (SSRP Surfaces 2018) integrating health provision and biodiversity conservation in this remote and threatened rainforest location and discuss some of the physical and ethical challenges that we have needed to address.

\section{Integrated health and conservation projects}

Integration of health and conservation is nothing new. For example, the British conservation movement from its Victorian beginnings was always partly motivated by the health benefits of nature (Selman and Swanwick 2010). The UK's National Parks were thus established mid last century following popular campaigns demanding that to conserve "the superb natural features and wildlife of our countrywide... extensive tracts [should] be preserved in their natural aspect and kept for public enjoyment and health" (CPRE 1938). Public health remains a priority of UK National Parks alongside conservation, with an ongoing national government initiative titled 'National Parks for National Health' (NPE 2017). Here however we will focus on relatively recent approaches developed in the global south that aim to produce win-wins by conceptually and operationally linking conservation and health (Ali 2013). Conceptual links support health by maintaining intact ecosystems and their health-related ecosystem services (e.g., upstream forest conservation to avoid increased diarrhoeal disease in communities downstream). Operational links in contrast provide medical services to increase goodwill for conservation programmes and/or increase community capacity for conservation (e.g., a mobile clinic providing childhood vaccination rounds) (Ali 2013).

Exemplar projects building operational linkages have been carried out in Borneo (Webb et al. 2018; Ali and Jacobs 2007), with the largest being that of Alam Sehat Lestari (ASRI). ASRI provides a hospital and mobile health patrols to communities living around the Gunung Palung National Park, with the aim of reducing their logging in the Park's buffer zone, a major local driver of which was the need to pay for remote and expensive health care. After a decade of its intervention, ASRI has reported marked improvements in health indicators, a community shift away from logging, and a parallel increase in secondary forest regrowth and stabilisation of primary forest loss (Webb et al. 2018). A similar approach has been taken in Uganda by Conservation Through Public Health (CTPH), which has worked to incentivise conservation through health service provision around Bwindi Impenetrable National Park, home to maybe one-half of the entire world's mountain gorillas (CTPH 2019). Like many projects primarily using operational linkages, CTPH has also carried out educational work to build community awareness of conceptual linkages between health and conservation. One relatively novel aspect of CTPH however, has been that by improving community health they have also aimed to reduce transmission of gastrointestinal and skin parasites from humans to critically endangered gorillas. Such anthroponotic diseases are a significant threat to apes (Ali et al. 2004) and endangered species more generally (Messanger et al. 2014), which the uni-directional focus on zoonotic hazards to humans often overshadows. Where wild populations persist in increasingly human-dominated landscapes, interventions such as CTPH's offer an additional way that servicing human health (SDG3) can support conservation of Life on Land (SDG15). That 'gorilla workers', such as tourist and conservation guides, were identified in Rwanda as disease-vectors themselves (Ali et al. 2004), also 
highlights the specific need for occupational health within the conservation workforce, often made up primarily of local people with little access otherwise to healthcare. In India, the Tulsi Foundation is carrying out just such work with 5000 frontline staff of the Wildlife Conservation Trust (Mumbai) in their tiger reserves, with the intention of both strengthening individual Ranger health and using existing Ranger infrastructure and personnel to service community health needs (Gadre and Trivedy 2019; Trivedy and Gadre 2019). A final category of integrated health and conservation projects are those working under the banner of 'Population, Health, Environment' (PHE), which usually explicitly incorporate family planning as a mechanism to attempt to reduce local population pressure on environments. PHE was jointly spearheaded in the 1990s by USAID and the World Wildlife Fund, with projects carried out from Nepal to Mozambique (Oglethorpe et al. 2008).

\section{Our joint intervention on SDGs for health and life on land in PNG}

We think some similar approaches to those outlined above may be fruitful in PNG given unmet health needs, and the stated desire for health services in multiple communities who have embraced biodiversity conservation.

In response to a community request, in July 2018 we conducted a combined clinical and rapid anthropological assessment of community health service needs and perspectives in the WCA, with the parallel provision of acute treatments and referrals (Fig. 1, protocol available). Our team included two UK researchers with clinical backgrounds (general practice and expedition medicine; ambulance service and parasitology), and two PNG researchers with prior experience in social and botanical studies. Over 2 weeks we conducted focus groups segregated by age-group and sex (young women, older women, young men, older men), and interviews with key informants (a clan leader and traditional healer, a local councillor, teachers, a conservation chairman). In addition, we collected medical history from the majority of villagers, and provided individual primary care assessments, with acute treatment where possible and referrals as required. Together the combined qualitative and quantitative data enabled us to develop a clear picture of community health status and priorities for service provision. This baseline data was then used to develop evidence-based targets for a funding proposal for a long term health intervention and expansion of the conservation area. The parallel provision of acute treatments and referrals gave immediate and tangible benefits to villagers as a result of their preexiting conservation project, and to our knowledge was the first ever visit by a doctor to the community.
As a result of our health needs assessment we received funding from the Darwin Initiative (DI 2019) for our current work, which links health to conservation both operationally and conceptually. It includes (1) a community health intervention tied to conservation, (2) community and schoolbased education in the health-related ecosystem services of intact forests, (3) creation of two new conservation areas, expansion of an existing one, creation of a no-impact zone within it and two new buffer zones on its borders, and (4) an evidence synthesis of related projects across the tropics.

At the time of writing (mid 2019) we are training villagers in medical evacuation and setting up a nurse-staffed aid post at Wanang, which will improve health service provision and community health, and enable the expansion and creation of the conservation areas. As Fig. 2 illustrates, as a result of the project the clans at Wanang are declaring a new no-impact zone (no hunting, no gardening) of 1000 ha within the WCA, and two new conservation areas of primary forest beyond it (500 ha and 400 ha, respectively). In addition, by providing access to the aid post to 9 villages surrounding WCA (c.1800 people) who own previously selectively logged forests which retain biodiversity value, a 3000 ha buffer zone (no logging, no agriculture) for WCA's intact forests is being declared.

Intact forests provide direct and indirect services supporting the well-being of communities (Pienkowski et al. 2017). We are developing and implementing educational programmes for different social groups on these benefits, in (1) BRC partner communities across PNG (c.5000 people), and (2) schools: at Wanang (c.260 pupils), and through BRC's established network (c.750 pupils). By 2022, a package of programmes will be made available nationally to the PNG Department of Education, and internationally to other members of the Planetary Health Alliance Primary/ secondary Education Working Group (PHA 2019a). We are also carrying out an evidence synthesis into the efficacy of health service incorporation in tropical forest conservation worldwide.

As regards SDG 3 (health and wellbeing), in the shortterm (3 years) we aim to significantly improve health for c. 2,000 people (10 villages, c.333 households) within c. $500 \mathrm{~km}^{2}$ currently lacking any medical services, building on health data to support co-design of a long term health plan. We will be evaluating the effectiveness of the health aspect of our intervention against our baseline health data. Many of the community defined health service priorities map clearly to SDG health indicators as illustrated here (alongside project targets): increased health worker density (from baseline of 0:2000 to 1:2000) (SDG3.D.1); improved proportion of children 1-year-old covered by all national programme vaccines (from $<10 \%$ at baseline to 60\%) (SDG 3.B.1); improved proportion of births attended by skilled health personnel $(0 \%$ at baseline to $60 \%$ in Wanang, at least $20 \%$ in buffer zone communities) (SDG 


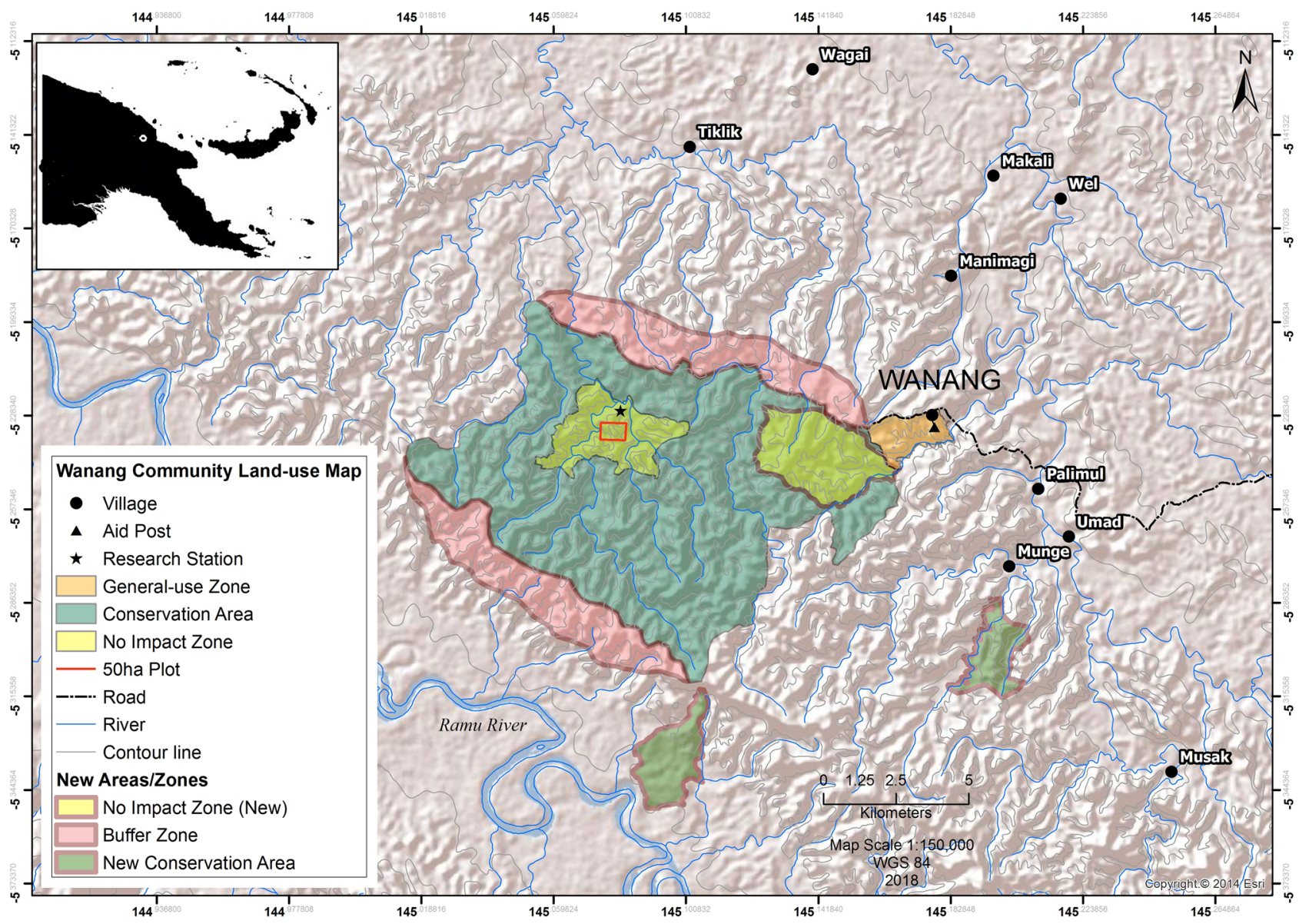

Fig. 2 Medical provision and the expansion of the Wanang Conservation Area

\subsection{2); increased proportion of women of reproductive} age (aged 15-49) who have their need for family planning satisfied with modern methods (from $0 \%$ at baseline to $50 \%$ in Wanang, and at least $20 \%$ in buffer zone communities) (SDG 3.8.1); reduction in number of people requiring interventions against neglected tropical diseases (specifically in this setting mycoses, scabies, yaws) (decreased $50 \%$ against baseline) (SDG 3.3.5); improved in-community availability of malaria Rapid Diagnostic Tests and treatment (from $0 \%$ baseline availability to $70 \%$ availability to all who seek aid) (SDG 3.3.3.). As a contribution to wider capacity building, we are developing monitoring and evaluation tools that can be taken up by PNG authorities for other posts. We have engaged the provincial health authority from the beginning and it has agreed to support the aid post. This may provide some financial sustainability, making it less reliant on organisations and aid budgets from abroad. However, given interruptions in PNG government funding are not unusual [much of the state network of aid posts are closed partly as a result (PNG DoH 2016)] our collaboration is committed to assisting health service provision at Wanang in the long-term.
Concerning SDG 15 (life on land), in the short-term ( 3 years) within the WCA we expect to see biodiversity gains as a result of the increased no-impact zones (Fig. 2), with a $25 \%$ increase in abundance of previously hunted mammal and bird species. We anticipate that addition of two new conservation areas beyond WCA (Fig. 2) will provide protection for an additional average of: (1) 34 individual birds/ ha (across all species); (2) 11 individuals of each of the ten rarest bird species in the area; (3) 15 tree species recorded across the combined protected areas. The WCA comprises a highly diverse forest type that is under the most intense pressure from logging in PNG. We expect the buffer zone of previously selectively logged forests will show a shift towards the ecological community composition of primary forest. We are conducting annual biodiversity surveys and inspections to determine the effectiveness of the conservation aspect of the intervention. In parallel, we are using household surveys before and after the health intervention to test whether attitudes to conservation in the communities previously outside the conservation collaboration change. We expect the educational part of our project to create greater awareness of the health and well-being benefits of 
intact forests in target communities beyond the Wanang area (c5000 people) and school pupils (c1010 in 6 village schools). We are using before and after testing to evaluate our educational intervention.

In the long-term we aim for the project to lay the foundations for a permanent health service for Wanang and neighbouring communities, ensuring sustainable support for an expanded WCA. Better health care, traditional land rights, biodiversity, and ecosystem services will have been secured through rainforest conservation. Materials developed for the Department of Education will support the education of PNG school pupils on the benefits of sustainable development pathways which preserve forests. As a contribution to the Planetary Health agenda, our evidence synthesis will enable a better-informed debate on incentivizing tropical forest conservation through medical interventions.

\section{Ethical issues}

The approach we have adopted inevitably raises concerns about seemingly providing health care services to targeted populations only on the condition they expand their existing conservation work, in which we have a vested interest-a potentially unethical imposition of conditionality upon what could be considered as a participant community's right to medical care [part of Article 25 of the Universal Declaration of Human Rights (UN 1948)]. This is an important and structural concern to be considered in planning any integrated health and conservation projects. Indeed, it could apply to any programmes that seek to integrate approaches to development goals addressing different rights, even if conditionality can be minimised as far as is reasonably possible. There is extensive literature on coercion and consent in research (e.g., Attanasio, Veruska and Marcos 2015; Williams 2008). However, since we could not identify specific ethical literature concerning integrated health and conservation projects, we explore the issues here.

We identified three possible interpretations of this important "conditionality concern" regarding our project:

1. Individual conditionality: the concern that the aid post would provide health care only to members of participant communities.

2. Group conditionality through active coercion: the concern that the aid post was being offered as an incentive to motivate, or coerce unwanted participation in a larger conservation project.

3. Group conditionality through passive coercion: the concern that the lack of available healthcare imposed such hardship on local communities that the circumstances alone would motivate or coerce participation in the conservation project.
We are confident we have been careful to account for each of the three interpretations of the conditionality concern in our project design, and we outline here how. First, in our project there will be no individual conditionality for access to acute or emergency care. Anyone presenting at the aid post in need of acute and emergency care will be provided with it regardless of their involvement in the conservation project. Nevertheless, it is the case that care for chronic conditions will be limited to members of communities participating in the conservation project. However, given that health care is inevitably rationed in all delivery systems, and that the services provided at the aid post will significantly improve existing provision in the region, we think this limited conditionality is a reasonable and justifiable compromise. Indeed, it can be argued that this limitation is analogous to the way in which a health clinic in a developed country would justifiably provide care for chronic conditions only to legal residents of its catchment area.

Second, the conservation project is being driven by local communities, which have defined their objectives and desired outcomes independently of us, and have proactively sought engagement from us to support and enable the achievement of these outcomes. Therefore, rather than demanding an expansion of the conservation area in return for the aid post (a type of coercive conditionality), we are instead seeking to better support the independently identified interests and needs of a community with which we already collaborate. Since this arrangement was proposed by the community as a way of fulfilling their linked objectives of increasing access to health care and increasing conserved land, we do not consider the provision of a health clinic as being used as a coercive tool with which to compel local communities to participate in activities that they would otherwise reject.

Third, in our project area non-participant communities have historically made agreements to permit access for industrial logging only in return for income and infrastructure from logging companies. However, these agreements have typically delivered very limited benefits for the relevant communities, which has prompted their desire to join the conservation project. Therefore, the apparent conditionality of "health care for conservation" can and arguably should be interpreted not as a case of passive coercion, but instead as an attempt to empower local communities to resist actual agreements with logging companies which have historically embodied the conditionality problem while also failing to deliver satisfactory outcomes.

Further potential concerns involve the cultural impacts of introducing biomedical interventions. Will building a health service catalyse conflict around the validity of traditional treatments? Are those of us from elsewhere viewed by clan members as "medical missionaries" come to convert them from their longstanding beliefs and practices? We have not 
experienced such problems at Wanang, and do not expect to for the following reasons. First, those practising folk medicine were included in planning the aid post from the start: through interviews, focus groups, skills training, and membership of the community health committee. Notably, a lead advocate of the post (a clan leader and father of co-author JP) is a traditional healer. We may be wrong and time will tell, but our impression is that these clan members see the aid post as an opportunity to shift role, rather than a threat to status. Second, we will champion traditional pharmacy when it can be demonstrated to be effective as a result of its characteristic features rather than any expectant beliefs (Howick 2017). This has been done elsewhere in PNG with tropical ulcer treatments (Prescott et al. 2017). Third, in the Madang region medical pluralism is common. Biomedical interventions may be seen as appropriate for some sicknesses ("sik bilong marasin"), but often this is compatible with continued belief and use of customary methods for "sik bilong ples" (village sickness) (Street 2014; Street 2010).

Nevertheless, if biomedicine does mostly supplant traditional medicine we would still view this, on balance, as an overall benefit. Some traditional PNG treatments are efficacious, but many are not, and none evolved to counter the new diseases (and new distributions of diseases) that have come to PNG since colonial contact (Jenkins 1989). This leads back to the second possible issue: that those of us from elsewhere could be viewed by clan members as "medical missionaries". This is a legitimate concern given the history of PNG, in which Christian medical missionaries attributed treatment success to supernatural powers as a tactic of evangelism (Jenkins 1989) [something that still continues (Street 2010)], and the health needs of an embryonic plantation economy 'transformed doctors into the decisive agents of colonial policy' (Denoon 2002). However, SURFACES began following explicit community request, and we do not seek to replace existing clan lifestyles at Wanang with those of our devising. Rather we aim to be allies, supporting the clans in their travel along sustainable development pathways of their own design. These seem largely to consist of preserving their forest and much of their cultures, but with the addition of improved healthcare, education, and access to key external goods.

Beyond our specific work, a range of ethical questions arise regarding integrated health and conservation projects. For example, the common use of medical volunteers/students from abroad may also bring the type of issues reported in other forms of medical volunteering, such as doctors working beyond the scope of their clinical speciality, and "the use of poor people in the Third World as "experimental fodder' to improve one's technical skills" (Bauer 2017). We are also aware of various forms of health-care charging in a number of programmes. To illustrate, one project (ASRI in Borneo) has charged individual patients for treatment (Wan et al. 2011), while another (Blue Ventures in Madagascar) encourages participants to become marketers of health products to their communities (Robson et al. 2017). These may all be very sensible steps in the settings concerned, but involve considerable ethical questions. There are likely to be many others, often not interrogated, and for this reason we suggest that bioethicists and public health practitioners should routinely be brought into teams at the project planning stage.

\section{Challenges to successful implementation}

While relatively early in our project roll-out, our experiences to date and knowledge of other projects has led us to reflect on some key challenges.

\section{Avoiding cross-sectoral blindness and achieving genuine interdisciplinary working}

Interdisciplinary collaborations are needed when carrying out integrated interventions across the SDGs, and are increasingly required by funders (for example the UK government Global Challenges Research Fund). Even groups carrying out interventions aimed at only single SDGs should still at least seek advice on how their work might affect the attainment of other SDGs. By not doing so, development interventions carried out by single-sector professionals have often had serious negative effects in sectoral areas beyond their sight (Waltner-Towes 2001). For instance, flood-control measures and dams have in many cases caused disease expansion [e.g., leishmaniasis (Waltner-Towes 2001), malaria (Kibret 2018), and schistosomiasis (Sokolow et al. 2017)]. Thus our first step in SURFACES was to build an interdisciplinary team from the UK and PNG who had the necessary expertise. This included public health epidemiology, tropical mycology, neglected skin diseases, PNG, remote medical care, social and medical anthropology, and conservation biology. However, there are significant challenges to making such teams interdisciplinary in reality. Many sustainability projects simply allocate work to different people/teams according to discipline, and thus remain multi-disciplinary, rather than working together across disciplines in ways that can produce new answers not available previously within the lore of each discipline (Stock and Burton 2011). To the extent we have been successful in bringing an interdisciplinary approach forward in SURFACES it has largely been facilitated by many of our investigators themselves having backgrounds in multiple disciplines (Fig. 3), which we have found makes bridging disciplinary divides across the team easier and quicker to achieve. In addition, working alongside each other in the field has been very useful. For example, during our initial health needs assessment 
Fig. 3 SURFACES Project interdisciplinary team. Institutions: Brighton (Pharmacy and Biomolecular Sciences, University of Brighton); BSMS (Brighton and Sussex Medical School); South (University of Southampton); IMR (Institute of Medical Research [PNG]); LS (School of Life Sciences, University of Sussex); LSH\&TM (London School of Hygiene and Tropical Medicine); GS (School of Global Studies, University of Sussex); BRC (Binatang Research Centre [PNG])

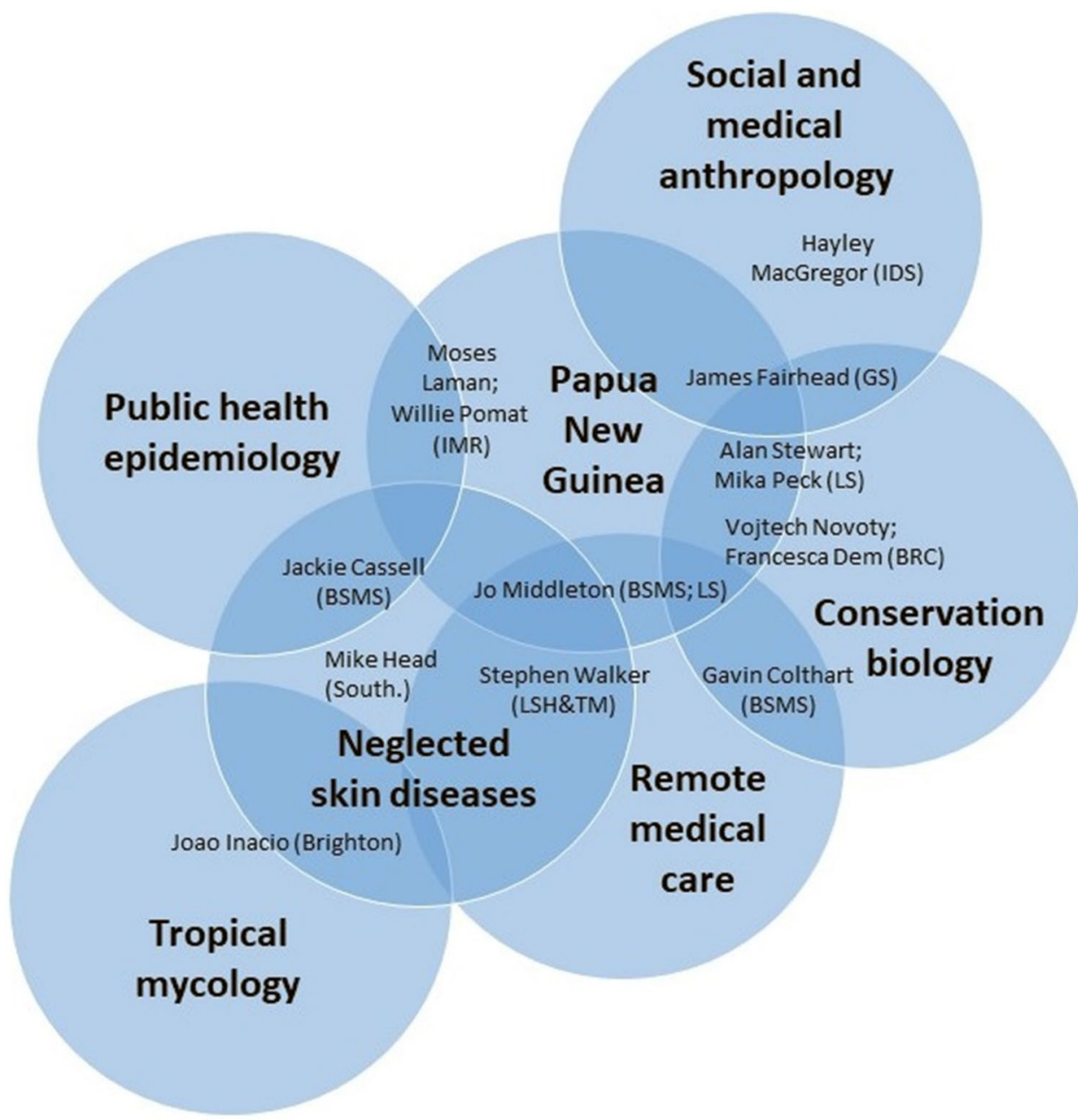

we were able to gain a fuller understanding of local burden and treatment of skin diseases by carrying out examinations and interviews together in a team which consisted of a botanist, general practitioner, social researcher, and disease ecologist. Yet, even though we started with a very broad group it has sometimes still been challenging to obtain advice from disciplines we had not initially considered (i.e., school education, bioethics, local history). This would have been even more difficult if we were not based in multidisciplinary academic institutions. In contrast, most existing integrated health and conservation projects we are aware of are carried out by NGOs, who may have less easy access to advice and collaboration beyond their organisational remits. Pooling of advice and expertise across projects may thus be helpful, and we return to this later in our conclusion.

\section{Weak evidence base justifying projects}

One of the earliest, but maybe unsurprising (Sutherland and Wordsley 2017), findings of our ongoing systematic mapping of evidence on integrated conservation and health programmes was the paucity of the published evidence base demonstrating their efficacy. Concerning projects with operational linkages, the majority we are aware of are localised bolt-ons to existing NGO conservation programmes. As such critical evaluations are often not carried out and are even more rarely published. We are however keen to bring together such NGO data that exists and welcome any additions to our mapping. Some of the more established integrated conservation and health projects have been carrying out evaluation research, but even these can lack comparator sites or accurate baseline data. Our observations of the field overall mirror those of an evidence synthesis that examined just the subset of such projects which could be characterised as adopting the Population, Health and Environment approach. It concluded projects often report changes in behaviour or environmental management (at a household or community level), with a presumption such changes will have produced the desired environmental objectives. However, the programmes rarely collected the ecological data needed to demonstrate the presumed effects (Yavinsky et al. 2015). Similarly, whilst evidence is building on the links 
between biodiversity and human health (Pienkowski et al. 2017; Sandifer et al. 2015; Keesing et al. 2010; Sala et al. 2009), we have seen less evidence that education on this conceptual link results in biodiversity conservation actually happening. We would thus encourage thorough, open monitoring and evaluation of all new projects. Given the present absence of a substantive, open and reliable evidence base some constructive scepticism towards NGO claims is warranted when planning interventions in this area. We are however aware of some high-quality evaluations in progress [for example, one (IIED 2019) on CTPH in Uganda], and we will be publishing evaluations of our PNG project in addition to our evidence synthesis of published and grey literature on projects worldwide.

\section{Temporal-spatial issues}

Our health work builds on a successful long-term conservation collaboration led by local clans who control their land and live in self-built houses, with food gardens, in extensive forest. At the time of the collaborations founding they were unfettered by the direct existence in their territory of outside institutions: there was no church, shop, NGO, or government building of any sort. The arrival of loggers on the forest frontier 19-years ago catalysed clan members to seek conservationist allies. Nearly two decades later the village has a government school (first built by the collaboration), but there is still no church, still no shop, and still no NGO to compete with the conservation board run by the clans who work with us, and through which most external material products are distributed. Thus one of the major facilitators of the success of the work at Wanang is the sites spatial remoteness and the temporal point along a developmental pathway at which the clans sought out conservationists. The resulting absence of competing institutions contrasts strongly with project sites with multiple NGOs or health-care providers, at which project evaluation may be far more difficult, and in which community enthusiasm may be muted due to social fragmentation. Such sites may be easier to reach but may be more challenging in which to carry out conservation-asdevelopment projects in general, and integrated health and conservation projects in particular.

\section{Planetary Health}

Emerging only in the last 7 years, Planetary Health as an interdisciplinary research field is focused on 'the human health impacts of human-caused disruptions of Earth's natural systems' (PHA 2019b); evidence of which has best been summarised by Whitmee et al. (2015) and Myers (2017). More broadly it has been envisioned as a social movement (Horton et al. 2014), whose aim is to 'safeguard both human health and the natural systems that underpin it' (Rockefeller Foundation 2018). Thus an editorial of one of the world-leading medical journals The Lancet can declare 'It's time to make protecting the biodiversity of our planet the next great cause [our emphasis] of planetary health' (Horton 2017).

We think the widening influence of Planetary Health provides a new and fertile ground for approaches that simultaneously aim to preserve land biodiversity (SDG 15) and increase human health (SDG 3). First, Planetary Health is acting as both a conceptual frame and a physical place for practitioners to meet [through the meetings of the Planetary Health Alliance (PHA 2019b)], enabling pooling of expertise and communication between groups. This is important because up until now (with the exception of PHE programmes), individual integrated health and conservation projects have operated largely in isolation. Second, Planetary Health is being enthusiastically embraced by many within medicine, from clinicians and clinical organisations (e.g., Veidis et al. 2019) to funding bodies (e.g., Rockefeller Foundation 2018), and this may enable a major scaling-up of programmes. Our mapping so far indicates integrated health and conservation projects have almost entirely been funded from within conservation budgets, yet the money available within medicine dwarfs that of conservation (Redford et al. 2014). Given empirical evidence forest conservation can significantly reduce the prevalence of major disease targets (Pienkowski et al. 2017), conservation itself may be a very efficient spend of health budgets. Such projects have also much to offer the wider Planetary Health movement. Social movements, especially those with ambitions as global as Planetary Health, need observable local victories to sustain momentum. On-the-ground projects like ours at Wanang, and others such as ASRI and CTPH, offer just such opportunities.

Our initial experience with the integration of forest conservation and health in PNG, and our knowledge of similar projects worldwide, indicates such interventions are worthy of wider adoption. We are thus keen to collaborate on their reproduction and evaluation, and welcome communication with any interested groups.

Author contribution Author order is alphabetical by surname, except the first (lead author) and last (principle investigator), with contributions to this publication detailed using the CRediT Contributor Taxonomy (https://casrai.org/credit/). Conceptualization, and funding acquisition: JM, JAC, GC, FD, JF, MGH, JI, ML, VN, MP, WP, AS. Supervision: JAC, AS. Writing-original draft: JM. Visualization: JM. Writing-review and editing: JM, JAC, GC, FD, JF, MGH, JI, MJ, ML, VN, MP, JP, WP, SS, PW, AS.

Funding This work is funded by grants from the Sussex Sustainability Research Programme (University of Sussex) (SSRP2016-023) and the Darwin Initiative (UK government aid funding) (26002). 


\section{Compliance with ethical standards}

Conflict of interest The authors declare that they have no conflict of interest.

Open Access This article is licensed under a Creative Commons Attribution 4.0 International License, which permits use, sharing, adaptation, distribution and reproduction in any medium or format, as long as you give appropriate credit to the original author(s) and the source, provide a link to the Creative Commons licence, and indicate if changes were made. The images or other third party material in this article are included in the article's Creative Commons licence, unless indicated otherwise in a credit line to the material. If material is not included in the article's Creative Commons licence and your intended use is not permitted by statutory regulation or exceeds the permitted use, you will need to obtain permission directly from the copyright holder. To view a copy of this licence, visit http://creativecommons.org/licenses/by/4.0/.

\section{References}

Ali R (2013) Approaching conservation through health. In: Colfer CJP (ed) Human health and forests. Earthscan, Abingdon, pp 317-332

Ali R, Jacobs SM (2007) Saving the rainforest through health care: medicine as conservation in Borneo. Int J Occup Environ Health 13:295-311. https://doi.org/10.1179/oeh.2007.13.3.295

Ali R, Cranfield M, Gaffikin L, Mudakikwa T, Ngeruka L, Whittier C (2004) Occupational health and gorilla conservation in Rwanda. Int J Occupa EnvironHealth 10:319-325. https://doi.org/10.1179/ oeh.2004.10.3.319

Attanasio OP, Veruska O, Marcos V (2015) Should cash transfers be conditional? Conditionality, preventive care, and health outcomes. Am Econ J Appl Econ 7:35-52. https://doi.org/10.1257/app.20130 126

Basset Y, Novotny V, Miller SE, Weiblen GD, Missa O, Stewart AJA (2004) Conservation and biological monitoring of tropical forests: the role of parataxonomists. J Appl Ecol 41:163-174. https://doi. org/10.1111/j.1365-2664.2004.00878.x

Bolnga JW, Hamura NN, Umbers AJ, Rogerson SJ, Unger HW (2014) Insights into maternal mortality in Madang province, Papua New Guinea. Int J Gynaecol Obstet 124:123-127. https://doi. org/10.1016/j.ijgo.2013.08.012

Bauer I (2017) More harm than good? The questionable ethics of medical volunteering and international student placements. Trop Dis Trav Med Vaccine 3:5. https://doi.org/10.1186/s4079 4-017-0048-y

CPRE (1938) Rural England: the Case for the Defence [cinema film], Council for Preservation [now Protection] of Rural England, London, UK. https://www.cpre.org.uk/magazine/opinion/item/5101the-long-path-to-our-national-parks. Accessed 18 June 2019

CTPH (2019) Bwindi Impenetrable National Park (Internet). https ://web.archive.org/web/20190613053758/http://www.ctph.org/ bwindi/. Accessed 13 June 2019

Denoon D (2002) Public health in Papua New Guinea: medical possibility and social constraint 1884-1984. Cambridge University Press, Cambridge, p 23

DI (2019) The Darwin Initiative (Internet). https://web.archive.org/ web/20190610205820/https://www.gov.uk/government/groups/ the-darwin-initiative. Accessed 10 June 2019

Gadre V, Trivedy C (2019) The health of forest staff: a multi-site assessment at tiger reserves from central India and western Ghats. Trans R Soc Trop Med Hyg 113(S1):S129. https://doi. org/10.1093/trstmh/trz090_Poster_Abstracts_Tuesday
Henning BM (2015) Market-based conservation in melanesia: contrasting expectations of landowners and conservationists. Conservat Soc 13:299-310. https://doi.org/10.4103/0972-4923.170409

Horton R (2017) Planetary health's next frontier-biodiversity. Lancet 390:2132. https://doi.org/10.1016/S0140-6736(17)32843-X

Horton R, Beaglehole R, Bonita R, Raeburn J, McKee M, Wall S (2014) From public to planetary health: a manifesto. Lancet 383:847. https://doi.org/10.1016/S0140-6736(14)60409-8

Howick J (2017) The relativity of 'placebos': defending a modified version of Grünbaum's definition. Synthese 194:1363-1396. https ://doi.org/10.1007/s11229-015-1001-0

IHME (2018) GBD country profiles-Papua New Guinea. https://www. healthdata.org/papua-new-guinea. Accessed 9 Feb 2018

IIED (2019) Are health investments paying off for endangered wildlife? https://web.archive.org/web/20190612223132/https:// www.iied.org/are-health-investments-paying-for-endangered -wildlife. Accessed 12 June 2019

Jenkins C (1989) The Amele and Dr Braun: a history of early experience with western medicine in Papua New Guinea. In: Frankel S, Lewis G (eds) A continuing trial of treatment: medical pluralism in Papua New Guinea. Kluwer Academic Publishers, Dordrecht, pp 181-198

Keesing F, Belden LK, Daszak P, Dobson A, Harvell CD, Holt RD et al (2010) Impacts of biodiversity on the emergence and transmission of infectious diseases. Nature 468:647-652. https://doi. org/10.1038/nature09575

Kibret S (2018) Time to revisit how dams are affecting malaria transmission. Lancet Planet 2:PE378-379. https://doi.org/10.1016/ S2542-5196(18)30184-0

Laurance WF, Kakul T, Tom M, Wahya R, Laurance SG (2012) Defeating the 'resource curse': key priorities for conserving Papua New Guinea's native forests. Biol Conservat 151:35-40. https://doi.org/10.1016/j.biocon.2011.10.037

Laurance WF, Kakul T, Keenan RJ, Sayer J, Passingan S, Clements GR et al (2010) Predatory corporations, failing governance, and the fate of forests in Papua New Guinea. Conservat Lett 4:95-100. https://doi.org/10.1111/j.1755-263X.2010.00156.X

Lim SS, Allen K, Bhutta ZA, Dandona L, Forouzanfar MH, Fullman $\mathrm{N}$ et al (2016) Measuring the health-related sustainable development goals in 188 countries: a baseline analysis from the global burden of disease study 2015. Lancet 388:1813-1850. https:// doi.org/10.1016/S0140-6736(16)31467-2

Messenger AM, Barnes AN, Gray GC (2014) Reverse zoonotic disease transmission (zooanthroponosis): a systematic review of seldom-documented human biological threats to animals. PLoS ONE 9:2. https://doi.org/10.1371/journal.pone.0089055

Mittermeier RA, Myers N, Thomsen JB, Da Fonseca GAB, Olivieri S (1998) Biodiversity hotspots and major tropical wilderness areas: approaches to setting conservation priorities. Conservat Biol 12:516-520. https://doi.org/10.104 6/j.1523-1739.1998.012003516.x

Myers SS (2017) Planetary health: protecting human health on a rapidly changing planet. Lancet 390:2860-2868. https://doi. org/10.1016/S0140-6736(17)32846-5

Nelson PN, Gabriel J, Filer C, Banabas M, Sayer JA, Curry GN et al (2014) Oil palm and deforestation in Papua New Guinea. Conservat Lett 7:188-195. https://doi.org/10.1111/conl.12058

NPE (2017) National Parks for National Health. https://web.archi ve.org/save/https://www.nationalparksengland.org.uk/newsand-media/press-releases/national-parks-for-national-health. Accessed 19 June 2019

Novotny V, Toko P (2015) Ecological research in Papua New Guinean rainforests: insects, plants and people. In: Bryan JE, Shearman PL (eds) The state of the forests of Papua New Guinea 2014: measuring change over period 2002-2014. University of Papua New Guinea, Port Moresby, pp 71-85 
Novotny V (2010) Rain forest conservation in a tribal world: Why forest dwellers prefer loggers to conservationists. Biotropica 42:546-549. https://doi.org/10.1111/j.1744-7429.2010.00658.x

Oglethorpe J, Honzak C, Margoluis C (2008) Healthy people, healthy ecosystems: a manual on integrating health and family planning into conservation projects. World Wildlife Fund, Washington

PHA (2019a) Planetary Health Education by Level. https://web.archi ve.org/web/20190610211637/https://planetaryhealthalliance. org/education-by-level. Accessed 10 June 2019

PHA (2019b) Planetary Health Alliance. https://web.archive.org/ web/20190619010806/https://planetaryhealthalliance.org/. Accessed 19 June 2019

DoH PNG (2016) Health sector annual management report. PNG Department of Health, Port Moresby

Pienkowski T et al (2017) Empirical evidence of the public health benefits of tropical forest conservation in Cambodia: a generalised linear mixed-effects model analysis. Lancet Planet 1:5. https://doi. org/10.1016/S2542-5196(17)30081-5

Pilang CL, Gray MA, Oprescu FI (2017) The evolution of the community health worker program in Papua New Guinea. Rural Remote Health 17:3961. https://doi.org/10.22605/RRH3961

Prescott TAK, Homot P, Lundy FT, Fang R, Patrick S, Rodrigo C et al (2017) Tropical ulcer plant treatments used by Papua New Guinea's Apsokok nomads. J Ethnopharmacol 205:240-245. https ://doi.org/10.1016/j.jep.2017.05.001

Redford KH, Myers SS, Ricketts TH, Osofsky SA (2014) Human health as a judicious conservation opportunity. Conserv Biol 28:627629. https://doi.org/10.1111/cobi.12290

Robson L, Holston M, Savitzky C, Mohan V (2017) Integrating community-based family planning services with local marine conservation initiatives in southwest madagascar: changes in contraceptive use and fertility. Stud Fam Plann 48:73-82. https://doi. org/10.1111/sifp. 12016

Rockefeller Foundation (2018) Planetary health. https://web.archi ve.org/web/20180513143835/https://www.rockefellerfoundatio n.org/our-work/initiatives/planetary-health/. Accessed 13 May 2018

Sala OE, Meyerson LA, Parmesan C (eds) (2009) Biodiversity change and Human Health: from ecosystem services to spread of disease. Island Press, Washington DC

Sandifer PA, Sutton-Grier AE, Ward BP (2015) Exploring connections among nature, biodiversity, ecosystem services, and human health and well-being: opportunities to enhance health and biodiversity conservation. Ecosys Serv 12:1-15. https://doi.org/10.1016/j. ecoser.2014.12.007

Selman P, Swanwick C (2010) On the meaning of natural beauty in landscape legislation. Landsc Res 35:3-26. https://doi. org/10.1080/01426390903407160

Shearman PL, Ash J, Mackey B, Bryan JE, Lokes B (2009) Forest conversion and degradation in Papua New Guinea 1972-2002. Biotropica 41:379-390. https://doi.org/10.111 1/j.1744-7429.2009.00495.x

Shearman P, Bryan J (2011) A bioregional analysis of the distribution of rainforest cover, deforestation and degradation in Papua New Guinea. Austral Ecol 36:9-24. https://doi.org/10.111 1/j.1442-9993.2010.02111.x

Sokolow SH, Jones IJ, Jocque M, La D, Cords O, Knight A et al (2017) Nearly 400 million people are at higher risk of schistosomiasis because dams block the migration of snail-eating river prawns. Phil Trans Biol Sci 372:20160127. https://doi.org/10.1098/ rstb.2016.0127

SSRP Surfaces (2018). Sussex sustainability research programmeSURFACES: An interdisciplinary approach to enhancing health in a vulnerable rainforest setting. Falmer, UK. https://web.archi ve.org/web/20180401122021/http://www.sussex.ac.uk/ssrp/resea rch/health-and-environment/enhancing-health-in-vulnerable-rainf orest-setting. Accessed 1 April 2018

Stock P, Burton RJF (2011) Defining terms for integrated (multi-intertrans-disciplinary) sustainability research. Sustainability 3:1090 1113. https://doi.org/10.3390/su3081090

Street A (2014) Biomedicine in an unstable place: infrastructure and personhood in a Papua New Guinea Hospital. Duke University Press, Durham and London

Street A (2010) Belief as relational action: christianity and cultural change in Papua New Guinea. J R Anthro Inst 16:260-278. https ://doi.org/10.1111/j.1467-9655.2010.01624.x

Stewart A, Peck M, Novotny V (2016) Final report to the Waterloo Foundation (July 2016): creating sustainable livelihoods whilst protecting rainforest in Papua New Guinea (PNG) from logging. University of Sussex, Falmer

Sutherland WJ, Wordsley CFR (2017) Evidence complacency hampers conservation. Nat Ecol Evol 1:1215-1216. https://doi. org/10.1038/s41559-017-0244-1

Trivedy C, Gadre V (2019) The exposure of forest staff in tiger reserves in central India to snake bites. Trans R Soc Trop Med Hyg 113(S1):S234. https://doi.org/10.1093/trstmh/trz090_Poste r_Abstracts_Thursday

UN (1948) The Universal Declaration of Human Rights Geneva: https ://web.archive.org/web/20190610221707/https://www.ohchr.org/ EN/UDHR/Documents/UDHR_Translations/eng.pdf. Accessed 10 June 2019

UN (2018) Sustainable development goals -17 goals to transform our world. Geneva: https://web.archive.org/web/20180404184935/ http://www.un.org/sustainabledevelopment/sustainable-devel opment-goals/. Accessed 15 April 2018

University of Sussex (2014) REF2014 impact case study: the conservation of tropical rainforests in Papua New Guinea and Ecuador. Higher Education Funding Council for England, Digital Sciences

University of Sussex (2015) Sussex ecologist's rainforest development work recognised by UN https://www.sussex.ac.uk/internal/bulle tin/staff/2015-2016/111215/alan-stewart-equator-prize. Accessed 30 Aug 2017

Veidis EM, Myers SS, Almada AA, Golden CD, on behalf of the Clinicians for Planetary Health Working Group (2019) A call for clinicians to act on planetary health. Lancet 393:2021. https://doi. org/10.1016/S0140-6736(19)30846-3

Wagia H (2018) Community views about logging in west New Britain, PNG. Email to Jo Middleton-j.middleton@ bsms.ac.uk. Accessed 22 May 2018

Waltner-Toews D (2001) An ecosystem approach to health and its applications to tropical and emerging diseases. Cad Saúde Pública 17:7-36. https://doi.org/10.1590/S0102-311X2001000700002

Wan M, Colfer CJP, Powell B (2011) Forests, women and health: opportunities and challenges for conservation. Intl Forest Rev 13:369-387. https://doi.org/10.1505/146554811798293854

Webb K, Jennings J, Minovi D (2018) A community-based approach integrating conservation, livelihoods, and health care in Indonesian Borneo. Lancet Planet. 2:S26. https://doi.org/10.1016/S2542 $-5196(18) 30111-6$

Whitmee S, Haines A, Beyrer C, Boltz F, Capon AG, Dias BF et al (2015) Safeguarding human health in the Anthropocene epoch report of The Rockefeller FoundationLancet Commission on planetary health. Lancet 386:1973-2028. https://doi.org/10.1016/ S0140-6736(15)60901-1

WHO (2018a) Papua New Guinea. https://www.who.int/countries/png/ en/. Accessed 9 Feb 2018

WHO (2018b) Indonesia. https://www.who.int/countries/idn/en/. Accessed 9 Feb 2018

WHO (2018c) Australia. https://www.who.int/countries/aus/en/. Accessed 9 Feb 2018 
WHO (2016) Malaria country profile, Papua New Guinea www.who. int/malaria/publications/countryprofiles/profile_png_en.pdf. Accessed 9 Feb 2018

Williams JR (2008) Consent. In: Singer PA, Viens AM (eds) The Cambridge textbook of bioethics. Cambridge University Press, Cambridge. https://doi.org/10.1017/CBO9780511545566.003

Yavinsky RW, Lamere C, Patterson KP, Bremner J (2015) The impact of Population, Health, and Environment Projects: A synthesis of the evidence. Population Council; The Evidence Project, Washington DC

Publisher's Note Springer Nature remains neutral with regard to jurisdictional claims in published maps and institutional affiliations. 